\title{
Baseflow representation module on MODCEL
}

\section{Módulo de representação de escoamento de base no MODCEL}

\author{
Pedro Lucas Cosmo de Brito ${ }^{1}$, Marcelo Gomes Miguez ${ }^{1}$, José Paulo Soares de Azevedo ${ }^{1}$ \\ ${ }^{1}$ Instituto Alberto Luiz Coimbra de Pós-graduação e Pesquisa em Engenharia - COPPE, Universidade Federal do Rio de Janeiro - \\ UFRJ, Rio de Janeiro, RJ, Brasil \\ E-mails: plcbrito@gmail.com (PB), marcelomiguez@poli.ufrj.br (MM), zepaulo@coc.ufrj.br (JPA)
}

Received: March 09, 2017 - Revised: January 19, 2018 - Accepted: February 26, 2018

\begin{abstract}
The land use characteristics of rural watersheds allow infiltration and consequent generation of groundwater flow, which constitutes a significant contribution to the hydrograph. Prior to this study, the MODCEL-COPPE/UFRJ model simulated only runoff, disregarding the losses occurred in rainfall-runoff process. Therefore, its application was more appropriate to urban watersheds, simulating flood events where surface flows prevail. This study aimed at representing the infiltration process and at incorporating the groundwater flow in the MODCEL's structure, making feasible the rural watersheds simulation thus expanding its applicability as a hydrological model. A case study was performed in a $417 \mathrm{~km}^{2}$ subcatchment of Piabanha River, located at Petrópolis/RJ. It's a predominantly rural watershed, with $80 \%$ of its area covered by forests. The model represented satisfactorily the seasonality and the magnitude of simulated recharges. In the parameter calibration procedure gave a coefficient of determination $\mathrm{R}^{2}=0.75$, comparing the calculated flows to the observed flows. During validation period, we obtained a coefficient of determination $\mathrm{R}^{2}=0.76$. The fit obtained was superior to that obtained in previous modeling of the same watershed by SMAP and MODCEL (previous version) and it was similar to TOPMODEL. In the hydrograph recession, new MODCEL presented $\mathrm{R}^{2}=0.75$, against 0.52 obtained in its previous version.
\end{abstract}

Keywords: Infiltration; Groundwater flow; Hydrograph.

\section{RESUMO}

As condições de uso e ocupação do solo de bacias hidrográficas rurais favorecem a infiltração e a consequente geração de escoamento subterrâneo, que constitui significativa contribuição para o hidrograma. Previamente à elaboração deste trabalho, o modelo MODCEL-COPPE/UFRJ somente simulava a chuva efetiva, desconsiderando as perdas ocorridas no processo de transformação de precipitação em escoamento superficial. Desta maneira, sua aplicação era mais adequada a bacias urbanas, na simulação de eventos de cheia, com predominância de escoamentos superficiais. Este estudo objetivou individualizar a infiltração e incorporar o escoamento de base à estrutura do MODCEL, viabilizando a simulação de bacias rurais e ampliando a sua aplicabilidade enquanto modelo hidrológico. Foi realizado um estudo de caso em uma sub-bacia do rio Piabanha de $417 \mathrm{~km}^{2}$, localizada em Petrópolis/RJ. Trata-se de uma bacia predominantemente rural, com $80 \%$ de sua área coberta por florestas. O modelo representou satisfatoriamente a sazonalidade e a magnitude das vazões. $\mathrm{Na}$ fase de calibração dos parâmetros obteve-se um coeficiente de determinação $\mathrm{R}^{2}=0,75$, comparando-se as vazões calculadas às observadas. No período de validação, $o R^{2}$ obtido foi de 0,76 . $O$ ajuste foi superior ao que se obteve em modelagens pregressas da mesma bacia via SMAP e MODCEL (versão anterior), e similar ao TOPMODEL. Na recessão do hidrograma, o novo MODCEL apresentou $\mathrm{R}^{2}=0,75$, contra 0,52 obtido na sua versão anterior.

Palavras-chave: Infiltração; Escoamento subterrâneo; Hidrograma. 


\section{INTRODUCTION}

The efficiency of Water Resources Management depends on the existence and accuracy of information about water availability. However, in a number of river basins there is a relative lack of data, due to the high costs and difficulties of operation and maintenance of the measurement equipment.

Therefore, mathematical modeling appears as an important tool for estimating water availability in space and time, helping the decision-making process, as it provides rapid responses to simulate the most varied scenarios.

A free mathematical model, developed at UFRJ and widely used in recent years, is MODCEL (MIGUEZ, 2001; MASCARENHAS; MIGUEZ, 2002; MIGUEZ et al., 2011). It is a distributed hydrodynamic model, based on the concept of flow cells (ZANOBETTI et al., 1970), which are homogeneous compartments used to characterize the surface of the basin. Each cell can assume particular patterns, representing soil use, hydrological characteristics and storage capacity. The entire area of the river basin is represented by the set of cells, which interact through links using different hydraulic equations (MIGUEZ et al., 2015b).

The process of transforming rainfall into flow is performed within each MODCEL cell. However, the hydrological model considers only the surface runoff, not representing the share of losses applied to the total rainfall, after separation of the surface runoff. That is, the MODCEL basically deals with surface hydrology and does not represent the process of formation of the baseflow, which can be informed as a boundary condition.

Therefore, the model has a greater applicability in flood studies, in which surface runoff is preponderant, particularly with greater accuracy for flow in urban basins, where the infiltration processes are reduced by the waterproofing that characterizes the urban soil use.

In recent years, many studies have applied MODCEL as a support tool, especially in studies of urban flood control measures, sustainable urban drainage and dam rupture wave propagation (e.g. MIGUEZ et al., 2009; REZENDE et al., 2013; VERÓL et al., 2013; BARBEDO et al., 2014; MIGUEZ et al., 2014).

However, in rural and peri-urban basins, where the soil use and occupation characteristics favor infiltration, the baseflow can be an important contribution to the hydrograph, especially in dry periods, of low - or no - precipitation (WADA et al., 2014; DE GRAAF et al., 2015; DE GRAAF et al., 2017). In these cases, the models should not disregard that part of the rain that infiltrates underground in long term simulations, which represent more than a simple flood event, because the results may be imprecise.

This work aims to incorporate the baseflow modeling into the MODCEL structure, increasing its applicability as a hydrological model, since it makes feasible the simulation of historical series in rural and peri-urban basins.

A case study is proposed in a sub-basin of the Piabanha River, from its source to Pedro do Rio fluviometric station, in Petrópolis / RJ. The Piabanha River is an important tributary of the Paraíba do Sul River, whose waters are widely used in southeastern Brazil. The Piabanha basin covers important municipalities of the Serrana Region and is predominantly rural, as well as the Pedro do Rio sub-basin, which has most of its area covered by forests.
The results of this work are compared with two previous studies that also performed hydrological modeling in the Pedro do Rio sub-basin: Lou (2010) and Gonçalves (2008).

The study of Lou (2010) used MODCEL itself, in its previous version, and incorporated the baseflow through boundary condition, in such a way that the baseflow was considered constant throughout the simulation time, without link real with the physical representation of the phenomenon. The recession curve obtained did not present a good fit to the observed flows.

Gonçalves (2008) simulated Pedro do Rio basin through two rainfall-runoff hydrological models: SMAP (concentrate) and TOPMODEL (distributed). In SMAP modeling, two different techniques of parameters automatic calibration were used: direct search, through Rosenbrock's method (ROSENBROCK, 1960), and indirect search by hyperbolic smoothing method (XAVIER et al., 2001). The SMAP modeling showed inferior adjustments to the TOPMODEL.

The comparison with the results obtained by the aforementioned authors aims to evaluate the potential of the new modeling concept proposed in the present work vis-a-vis the previous version of MODCEL itself and to two well-established and widely used hydrological models.

\section{MODCEL}

MODCEL is a distributed hydrological-hydraulic model. It has a simple academic interface, but capable of solving complex problems, with emphasis on the representation of urban basins.

The rainfall-runoff transformation process is carried out within each cell, through the rational method (MIGUEZ et al., 2015a). Each cell is assigned a runoff coefficient, according to its soil use and occupation property. In each time interval, the effective rain in a cell is obtained by multiplying the rain occurring by its runoff coefficient. A more detailed description of MODCEL is presented in the Appendix $\mathrm{A}$ in the end of the article.

\section{ADAPTATIONS IN MODCEL}

The purpose of this work was to adapt the capacity of representation of the MODCEL, which has a modular construction, to solve the limitation of the non-consideration of baseflow in its structure.

Thus, the proposal for modification of the MODCEL consists in the creation of an underground cell, which represents a soil portion of the hydrogeological basin, and the creation of a link between cells, which represents, in a simple way, the runoff in the soil, between two underground cells or between these and the river.

For the creation of the underground cell, the following assumptions were adopted:

- Hydrogeological basin is coincident with hydrographic basin, so that the superficial cell flowing into the underground cell has the same area of it;

- The underground cell works as a reservoir-type cell, having as parameters: (i) the total area, equal to the area of the superficial cell above it; (ii) the bottom's depth, defined 
by terrain topography (so that the reservoir depth is the difference between the bottom depths of the superficial and underground cells); (iii) a underground depth-area curve, the starting point of which is the bottom depth with area associated with the refill surface, equivalent to the storage area of the surface cell, with depth increments keeping the area constant (assuming a prismatic reservoir). From the depth-area curve, the stored volumes (depth-volume curve) are estimated;

- This new reservoir cell receives supplementary information relating to a soil void index;

- The water level in this "inside ground" reservoir is obtained by dividing the depth obtained in the mass balance of this cell by the value of the soil void index. In principle, a value of 0.50 was adopted for that index. This is a value that may be better evaluated in the future, but at the moment, for the purpose of simplifying the model and the calibration process, it did not consist of a calibratable parameter;

- The infiltrated quantity is calculated from a coefficient obtained by subtracting superficial runoff and other losses by plant interception or evapotranspiration. Figure 1 illustrates the proposed design.

The portion of the rain that reaches the underground cell, and generates baseflow, is initially discounted from superficial cell's runoff coefficient $(\mathrm{C})$ and the $\mathrm{X}$ parameter, also dimensionless, which incorporates losses by interception and evapotranspiration. The value of 0.38 for the $\mathrm{X}$ parameter was adopted, according to basin land use characteristics, according to methodology proposed by FISRWG (2001).

The new link created, in turn, to represent the flow out of the underground cell, was based on Darcy's law (TUCCI et al., 2009). Starting from Equation 1, this was manipulated to clarify the flow according to the water level depths, in adjacent cells, transferring the uncertainty and grouping the other terms within a single coefficient to be introduced into the model, reaching the final proposed equation according to the development shown below:

$v=k \cdot i$

Where:

$v$ : Flow speed in porous medium (volumetric flow of water in the soil, defined by the volume drained per unit of total area grains and voids - and per unit of time), in $\mathrm{m}^{3} / \mathrm{m}^{2} / \mathrm{s}(\mathrm{m} / \mathrm{s})$, can be replaced by $\frac{Q}{A}\left(\frac{m^{3} / s}{m^{2}}\right)$, where $\mathrm{Q}$ is the flow and $\mathrm{A}$ is the area of the flow cross-section between two cells;

$k$ : Permeability, in $\mathrm{m} / \mathrm{s}$;

$i$ : Hydraulic gradient or $\frac{\Lambda Z}{\Lambda L}$, that represents the difference in water depth by the distance between two cells, in $\mathrm{m} / \mathrm{m}$.

So we get to Equation 2:

$\frac{Q}{A}=k \cdot \frac{\Lambda Z}{\Delta L}$

But considering the "i" cell, upstream, and the " $j$ " cell, downstream, by hypothesis, and calling $Z_{i}$ the cell water level depth and $Z_{F}$ the cell bottom depth, in meters, we have:
$A=\left(Z_{i}-Z_{F_{i}}\right) \cdot B$

where $B$ is the width of the connection between two " $i$ " and " $j$ " cells (flow channel width, in meters).

Considering $\Lambda Z=Z_{i}-Z_{j}$ and introducing (3) in (2):

$Q=k \cdot\left(Z_{i}-Z_{F_{i}}\right) \cdot B \cdot \frac{\left(Z_{i}-Z_{j}\right)}{\Lambda L}$

Grouping $\frac{k}{\Lambda L}$ in a new composite coefficient:

$Q=k^{\prime} \cdot B \cdot\left(Z_{i}-Z_{F_{i}}\right) \cdot\left(Z_{i}-Z_{j}\right)$

Equation 5 was then introduced into the model as a new link. The new coefficient, $k^{\prime}$ (expressed in $\mathrm{m} \mathrm{s}^{-1} / \mathrm{m}$, or $s^{-1}$ ) is a calibration parameter that covers the simplifications and uncertainties of this new modeling. This is the soil permeability per meter between two underground cells. Figure 2 design illustrates the flow representation between two underground cells, indicating the variables presented in the equations.
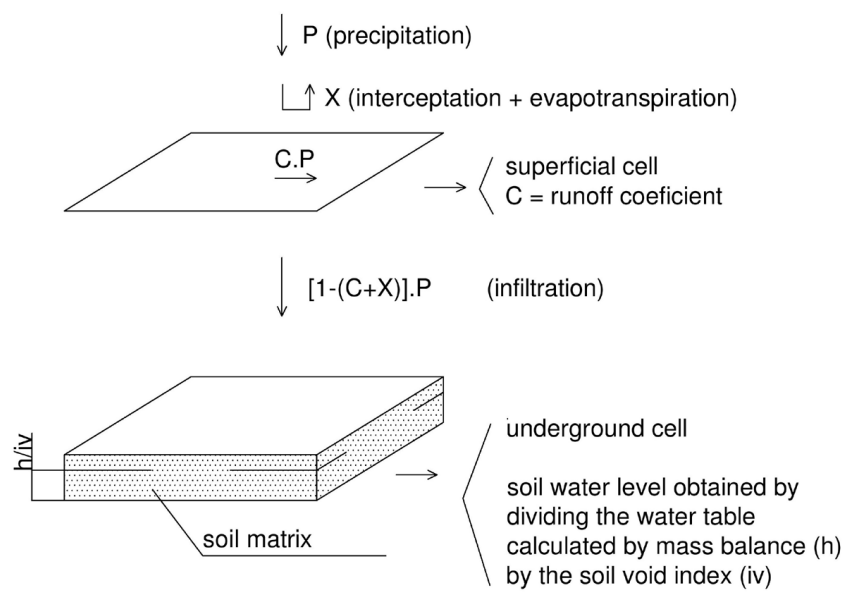

Figure 1. Schematic representation of the underground cell.

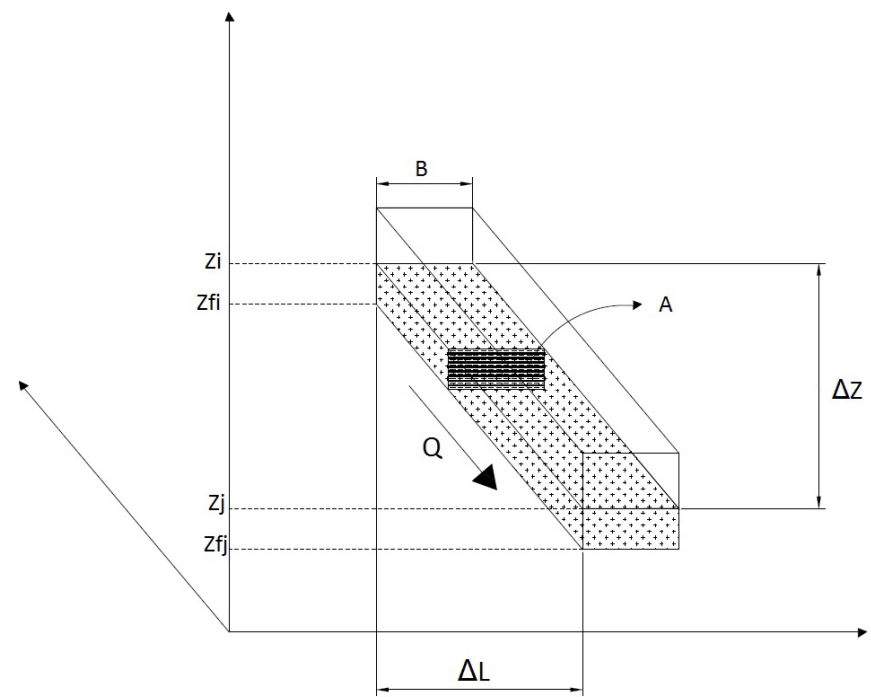

Figure 2. Schematic representation of the flow between two underground cells. 


\section{STUDY AREA CHARACTERIZATION}

Piabanha River is an important tributary of Paraíba do Sul River right bank. It has about $80 \mathrm{~km}$ of extension and its basin, completely inserted in Rio de Janeiro state, has an area of approximately $2,045 \mathrm{~km}^{2}$, covering, wholly or partially, the municipalities Petrópolis, Teresópolis, São José do Vale do Rio Preto, Areal, Três Rios, Paraíba do Sul and Paty do Alferes.

Pedro do Rio Basin has approximately $417 \mathrm{~km}^{2}$ of area and is completely inserted in Petrópolis town. Its batch point is Pedro do Rio fluviometric station, namesake of the town's fourth district, which is located in the Microrregião Serrana of the Rio de Janeiro state (Figure 3).

In relation to land use, Pedro do Rio Basin has an extensive preserved area. About $80 \%$ of its area is covered by forests (BRITO, 2014). Still, there is some urban occupation, especially more upstream, where Petrópolis urban district develops (Figure 4).

It is therefore a predominantly rural basin. Considering the runoff coefficients of Table 1, the basin presents an average

Table 1. Runoff coefficients adopted (Adapted of REZENDE et al., 2013).

\begin{tabular}{cc}
\hline Land use & Runoff coefficient \\
\hline Rock outcrop & 0.5 \\
Agriculture & 0.3 \\
Water & 1.0 \\
Forest & 0.2 \\
High density urban occupation & 0.8 \\
Low density urban occupation & 0.5 \\
Medium density urban occupation & 0.6 \\
Pasture & 0.4 \\
Secondary vegetation at an early stage & 0.4 \\
\hline
\end{tabular}
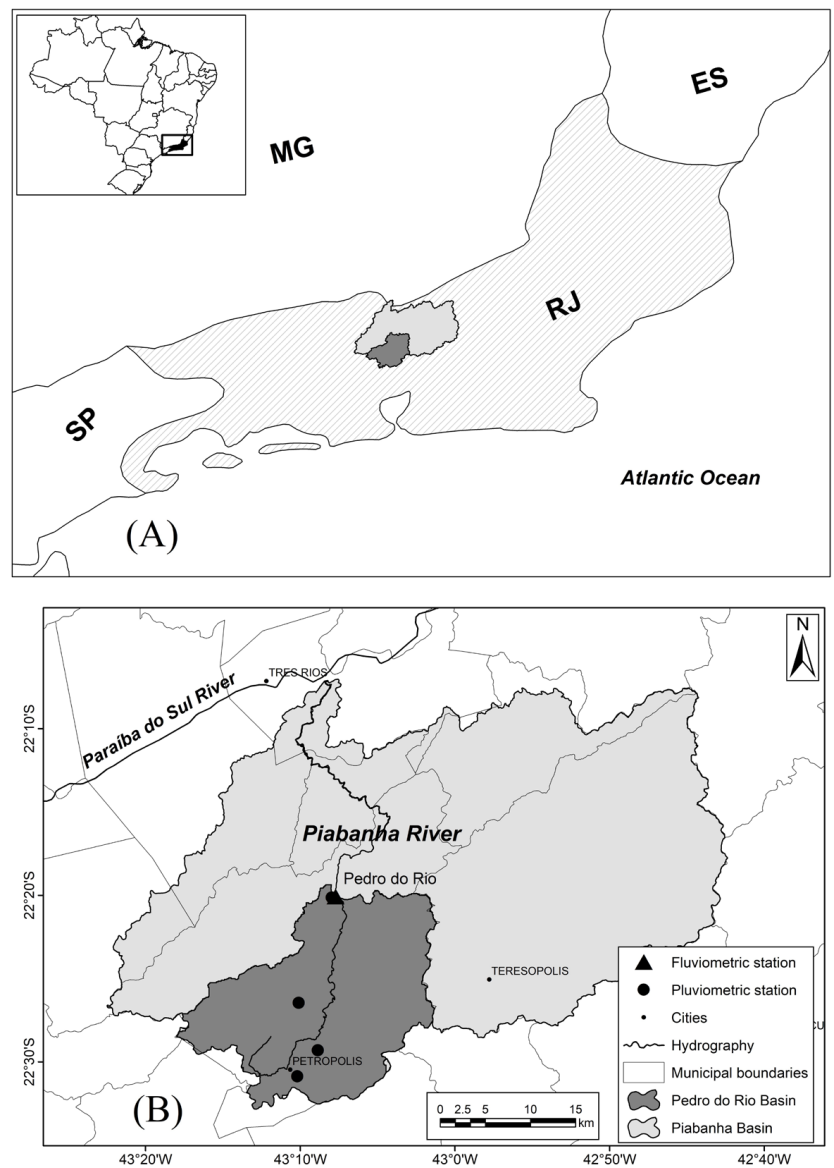

Figure 3. (A) Location of Pedro do Rio Basin in Rio de Janeiro state. (B) Pedro do Rio Basin and meeting of Piabanha River and Paraíba do Sul River.

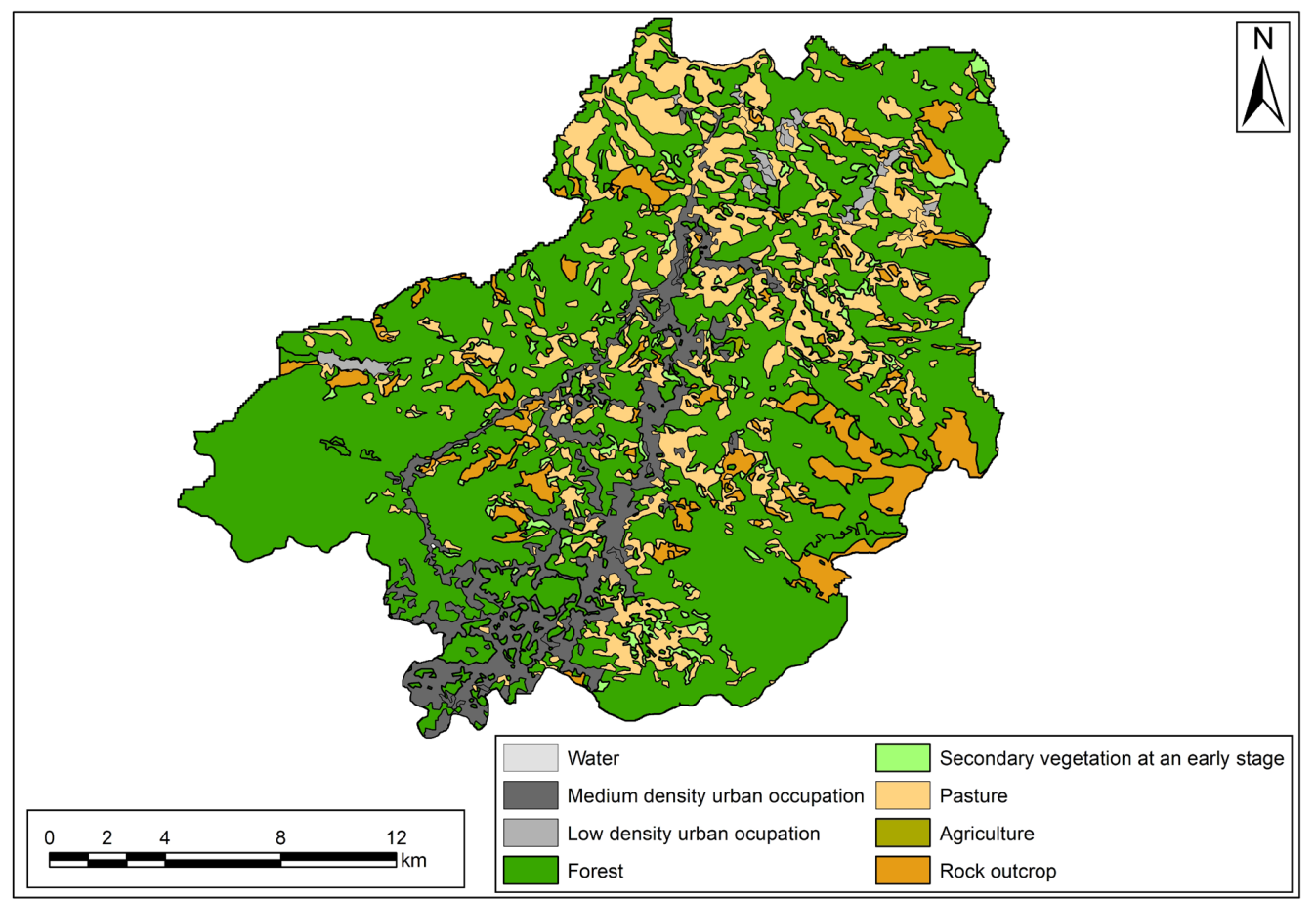

Figure 4. Pedro do Rio Basin land-use map. 
"C" of 0.30 . This value suggests that infiltration, which recharges the aquifer and gives rise to baseflow, is not negligible and cannot be disregarded in a long-term modeling.

\section{PRE-PROCESSING}

The first model preprocessing step consists of interest region discretization in flow cells. Because it is an essentially rural basin, the division of its drainage area into surface cells followed a logic of sub-basins, which were automatically generated through geoprocessing technique, with some adaptations to facilitate the use of MODCEL (Figure 5).

Just the main river was modeled - the small tributaries were incorporated into the sub-basins. The river was divided into 3 sections (3 channel-type cells), which communicate through canal-type connections. Two more "fictitious" river-type cells of were also created, downstream of cell 3 , to receive water from the main river and transfer it downstream, in an extension of the stretch of interest, in order to be able to unload these waters freely, without the need to define a downstream contour condition and without influencing the results in the Pedro do Rio section. This is a device known as "extended virtual domain", or "virtual batch point", which shifts, out of the problem's interest domain, points or places liable to introduce undesirable disturbances in the solutions in domain areas, where satisfactory results are sought (VERÓL, 2010).

In order to simplify the topography of sub-basins, natural surface cells were attributed to them. These are cells that represent non-urbanized surfaces, with distinct parameters of cells representing basin urban portions, with flood plains occurring. The storage area, or flood area, of each cell was estimated on the basis of physical criterion, related to the valleys topography. Figure 6 shows the basin Digital Elevation Model (DEM), with altitudes ranging from 660 meters, in the drainage network vicinity, and 2,272 meters, in the furthest regions of it. The region of the basin with depth equal to or less than $750 \mathrm{~m}$ was defined as storage area.

For the connections between surface cells that are lateral to river sections $(12,16,14,17,15$ and 19), where the flow exchanges occur along the channel entire length, broad crested weir links were defined, whose parameters are the width and depth of the spillway (which represents, in this case, the cell interface with the river stretch) and the spill coefficient. As for the cells 11,13 and 18, because they are upstream of the stretches of river with which they connect, surface flow links are given, which represent the Saint-Venant dynamic equation, without inertia terms, and replace, here, the channel function. The surface flow link parameters are the distance weighting coefficient between the slave cell and the main cell, the slave cell width, the Manning roughness coefficient, and the total distance between cell centers.

The first step in the insertion of baseflow into the model structure was the creation of underground cells, which contribute to river stretches parallel to superficial cells.

Then, in addition to the nine natural surface cells (11 to 19), nine subterranean cells (110 to 190) were created. They were assigned a new type - reservoirs that take into account a soil voids index. We have designed prismatic reservoirs with two pairs of depth $x$ area values: $(\mathrm{CF}, \mathrm{AA})$ and $(\mathrm{CF}+10$; $\mathrm{AA})$, where $\mathrm{CF}$ is

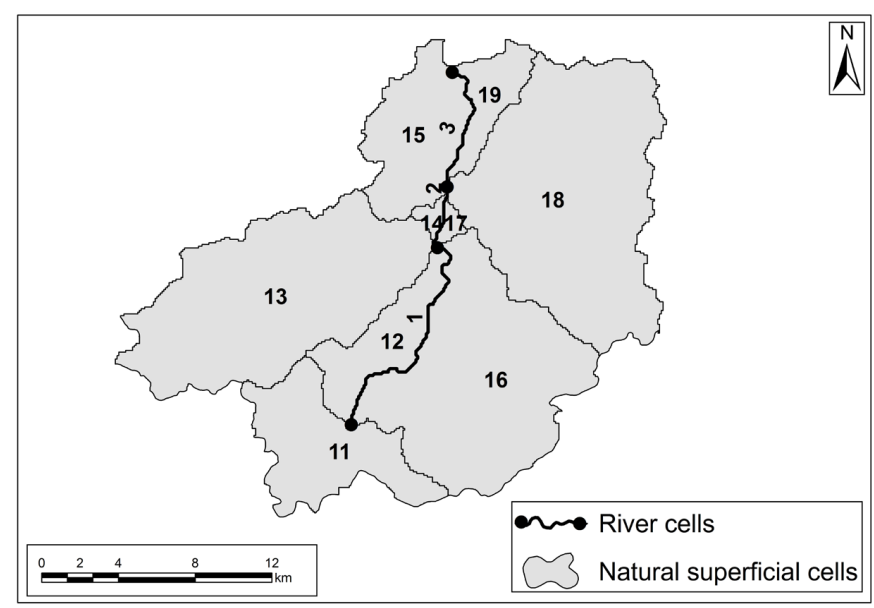

Figure 5. Pedro do Rio Basin cells division map.

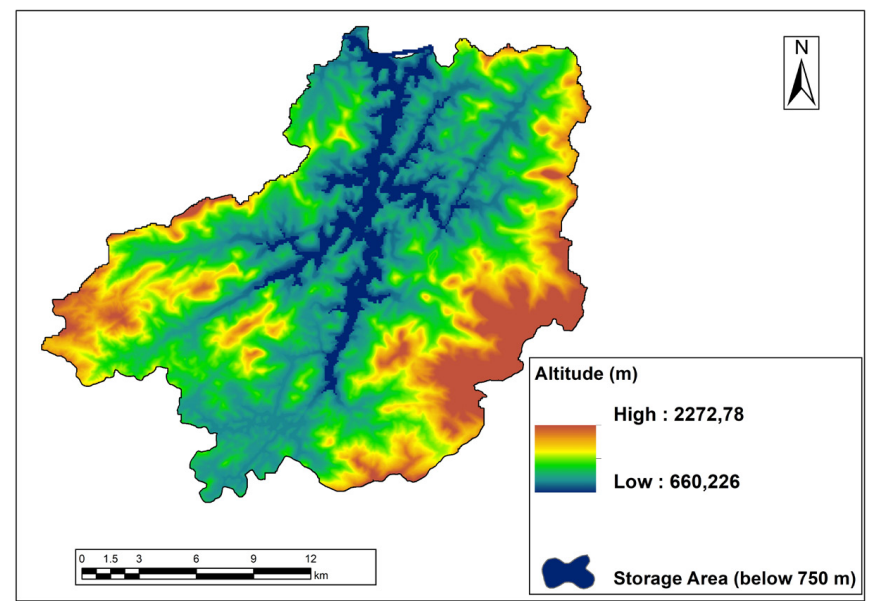

Figure 6. DEM and storage area.

the bottom depth of the underground cell that connects to the channel cell and AA is the underground cell storage area defined on the basis of the same natural surface cell criterion. Volumes are determined from water depth variation inside the cell at each time interval. This means that model represents underground cells as "vertical walls" reservoirs, in a simplified way, since they only connect to the surface cells storage/flooding areas. The additional 10-meter elevation is an exaggerated value defined as a modeling strategy to ensure there would be no extravasation of this underground reservoir.

The subterranean cells connect to the same channel cells as the corresponding surface cells, i.e., in the same way that cell 12 connects to cell 1 , cell 120 also connects to cell 1, through the new Darcy's Law-based link, providing another contribution to the river flow. Figure 7 shows the model topology with the cell diagram and links for simulation.

After defining the runoff coefficients for each basin land use (Table 1) and calculating the $\mathrm{C}$ coefficient of each surface cell (sub-basin), by means of area-weighted averages, the following rule was reached for the model cells runoff coefficients: 


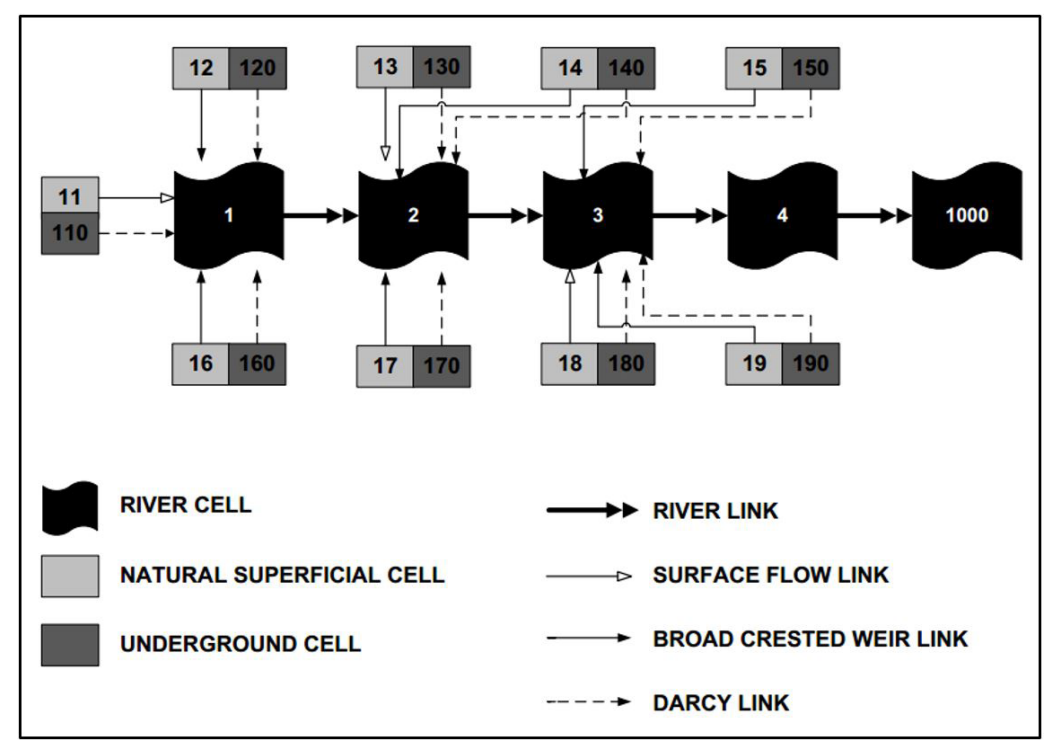

Figure 7. Model topology.

- Channel cells (type 0): $C_{0}=1$ (there is $100 \%$ runoff);

- Superficial cells (type 4): $C_{4}=C$ (the cell's runoff coefficient itself defines the runoff percentage);

- Underground cells (type 6): $C_{6}=1-C-X$ (the surface cell's runoff coefficient and the losses by interception and evapotranspiration are deducted from the total rainfall, remaining the rain percentage that infiltrates and generates baseflow, according to Figure 1).

The parameter $\mathrm{X}$ incorporates losses by evapotranspiration and vegetal interception. Thus, the part of the rain that is not lost before reaching the ground and does not flow superficially, infiltrates and becomes available to the underground cells.

\section{CRITERIA FOR SIMULATION ANALYSIS}

Data from four pluviometric stations of the National Water Agency (ANA) were used as input to the model, as well as a fluviometric station that delimits the basin, for comparison of results and parameters calibration (Table 2).

The influence area of each pluviometric station was determined through Thiessen Polygons, defined automatically through geoprocessing. The simulation period 2001-2004 was chosen because it presents data that is consisted and without failures. Thus, the year 2001 was defined for calibration and the period 2002-2004 for validation. The time interval of the simulation was daily.

The results were analyzed in terms of usual statistical functions in hydrological modeling - Determination Coefficient $\left(\mathrm{R}^{2}\right)$, Nash-Sutcliffe Efficiency (ENS), ENS of the flows natural logarithm, Kling-Gupta Efficiency (KGE) -, permanence curves (with particular comparison between flows Q50, Q90, Q95 and Q90/Q50 ratio) and comparison with results from SMAP (two configurations) and TOPMODEL models from previous studies.
Table 2. Hydrological stations used.

\begin{tabular}{ccccc}
\hline $\begin{array}{c}\text { Station } \\
\text { Code }\end{array}$ & Name & Type & Lat $\left(^{\circ}\right)$ & Lon $\left(^{\mathbf{}}\right)$ \\
\hline 02243009 & Petrópolis & Pluviometric & -22.51 & -43.17 \\
02243010 & Itamarati-SE & Pluviometric & -22.49 & -43.15 \\
02243011 & Rio da Cidade & Pluviometric & -22.44 & -43.17 \\
02243012 & Pedro do Rio & Pluviometric & -22.33 & -43.14 \\
58405000 & Pedro do Rio & Fluviometric & -22.33 & -43.13 \\
\hline
\end{tabular}

\section{RESULTS AND DISCUSSIONS}

\section{Calibration}

Once the model assumptions were defined and the input data entered through information representing the physical processes, the main model calibration parameter was the link coefficient $\left(k^{\prime}\right.$ in Equation 5, expressed in $\mathrm{m} \mathrm{s}^{-1} / \mathrm{m}$, or $\left.s^{-1}\right)$. After parameter manual settings, a value of 0.0002 was reached. Physically, this means a soil permeability of $0.0002 \mathrm{~m} / \mathrm{s}$ per meter of distance between the two underground cells.

Figure 8 shows the model response hydrograph for the calibration period, compared to the observed hydrograph.

The visual inspection of the hydrograph indicates that the model, in general, presented a satisfactory response, compared to the observed flows. The initial period of the first days of the simulation, in which there was no good fit between observed and calculated flows, is necessary to "warm up" the model, so it is disregarded in the analysis.

The model represented very well the flows seasonality, with clear distinction between dry and rainy periods and adequate representation of hydrograph recession.

In relation to the flows magnitudes, a good hit is observed, especially in the minimum ones, that occur in the dry period - from May to September. Some extreme outflows have been 


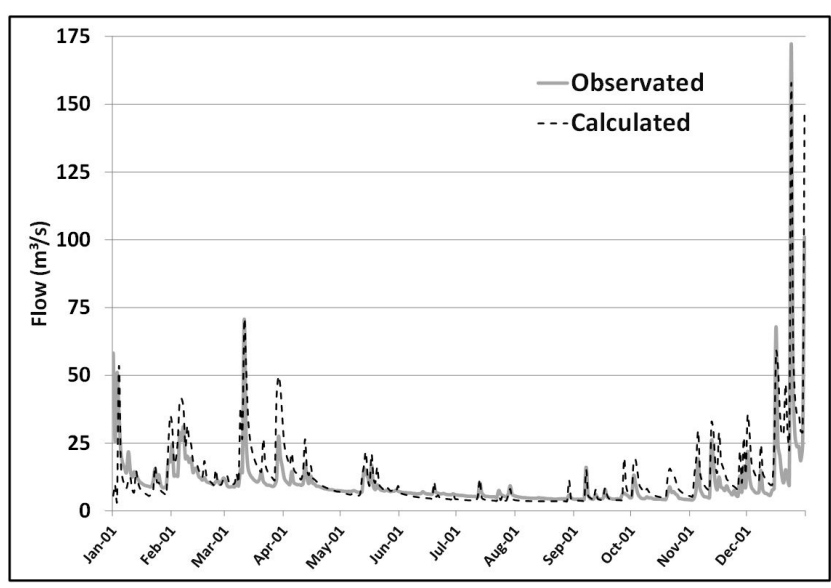

Figure 8. Hydrograph of the calibration period (2001).

overestimated, as shown in the hydrograph. One of the possible reasons for these overestimations is the little spatial refinement used in this modeling. The Rational Method, used in the MODCEL structure for rainfall-flow transformation, applies to small basins. The sub-basins that defined the cells have areas between 2 and $117 \mathrm{~km}^{2}$. This poorly-refined cells representation decreases the damping effect, which occurs in the surface flows exchange throughout the cells and which finds in each cell a storage reservoir. A more detailed division would therefore have the same effect as a series of reservoirs.

In order to better evaluate the baseflow representation, main contribution of the work, Figure 9 shows a zoom in the recession period, between 15-Apr-01 and 15-Aug-01.

When we highlight the recession curve, we can see that there was a good adjustment, but there is a tendency to overestimate peak flows and underestimate minimum flows in the dry quarter. The $\mathrm{R}^{2}$ for the recession period was 0.88 .

For the simulated and observed flows, we also plotted the permanence curves (Figure 10), from which the reference flows Q50, Q90, Q95 and Q50/Q90 ratio were determined (Table 3).

Although the observed and calculated reference flows values are close, the calculated minimum flows are smaller (from Q60 below), showing in numbers the underestimation trend observed in the hydrograph.

In general, the model presented good correlation in the calibration phase. Statistically, this can be measured through the statistical functions expressed in Table 4.

\section{Validation}

For the validation period (2002 to 2004) the parameters obtained in the calibration were used. The results are shown in Figure 11.

The validation period provided a more consistent analysis of model performance, since three complete hydrological years were simulated.

As in the calibration phase, the recession periods of the validation years were also zoomed, from April 15 to August 15 of each year (Figure 12, Figure 13 and Figure 14).

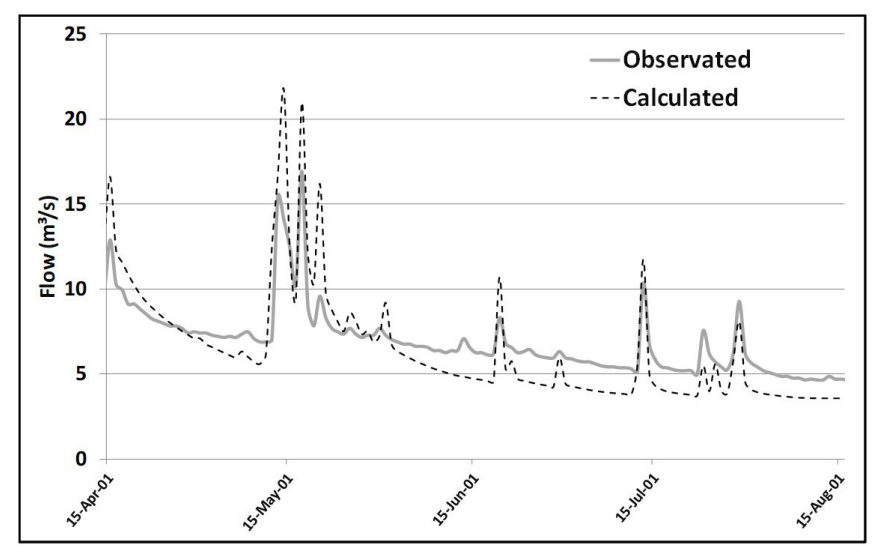

Figure 9. Calibration period hydrograph (2001), with emphasis on the recession curve.

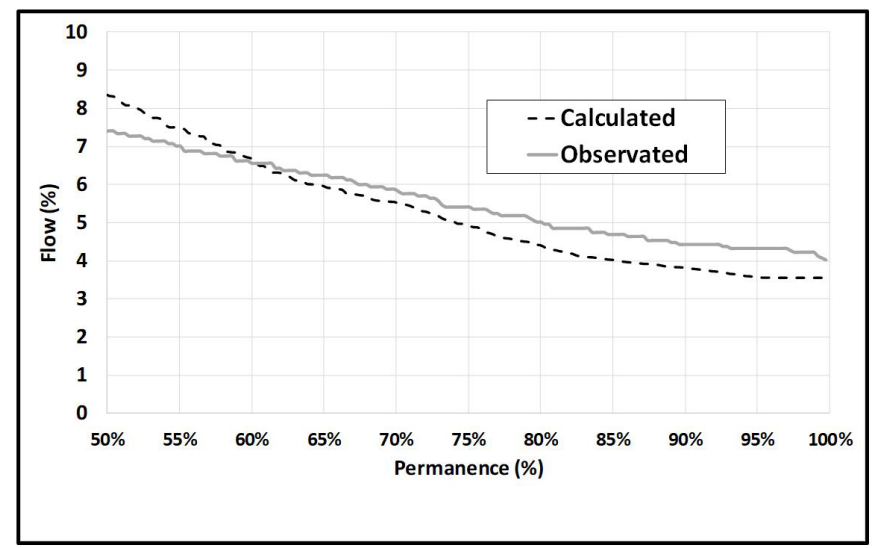

Figure 10. Calibration period permanence curves (2001).

Table 3. Calibration period reference flows (2001).

\begin{tabular}{ccc}
\hline Reference & $\begin{array}{c}\text { Observed Flow } \\
\left(\mathbf{m}^{3} / \mathbf{s}\right)\end{array}$ & $\begin{array}{c}\text { Simulated Flow } \\
\left(\mathbf{m}^{3} / \mathbf{s}\right)\end{array}$ \\
\hline Q50 & 8.5 & 7.5 \\
Q90 & 3.8 & 4.5 \\
Q95 & 3.6 & 4.3 \\
Q90/Q50 & 0.5 & 0.6 \\
\hline
\end{tabular}

Table 4. Statistical functions obtained during calibration.

\begin{tabular}{cc}
\hline Statistical function & Value \\
\hline $\mathrm{R}^{2}$ & 0.75 \\
Nash-Sutcliffe Efficiency (ENS) & 0.60 \\
ENS of the flows natural logarithm & 0.42 \\
Kling-Gupta Efficiency (KGE) & 0.67 \\
\hline
\end{tabular}

As in the calibration phase, a good fit is observed in the recession curves, with some peak flows overestimations and minimum flows underestimations. The $\mathrm{R}^{2}$ specifically for the recession periods was 0.71 . Let us look at the permanence curve and the reference flows of the validation phase (Figure 15 and Table 5). 


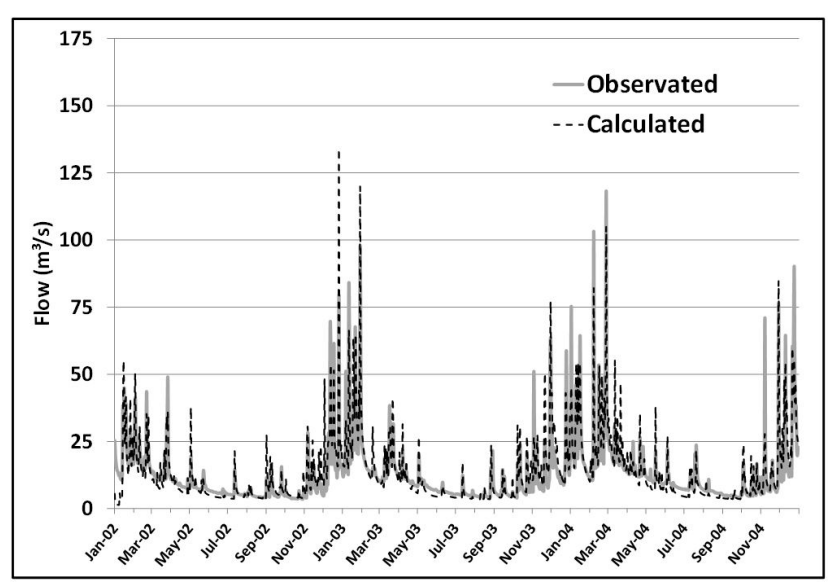

Figure 11. Validation period hydrograph (2002-2004).

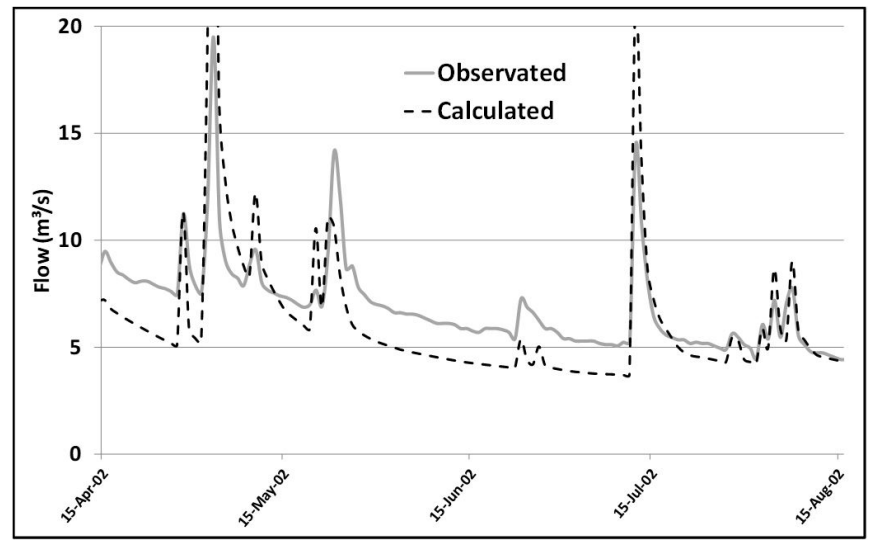

Figure 12. Validation period hydrograph (2002), highlighting the recession curve.

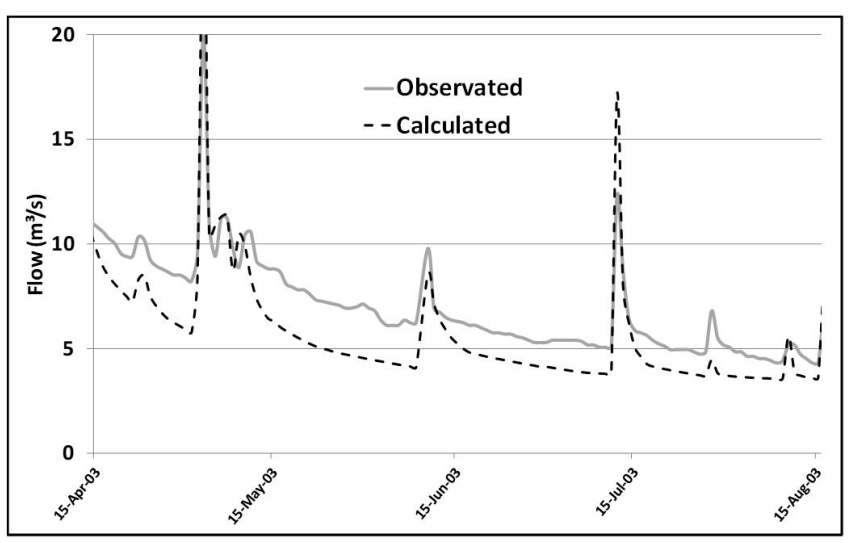

Figure 13. Validation period hydrograph (2003), highlighting the recession curve.

Again, the values are close, with the simulated flows always lower, reinforcing the underestimation tendency of the minimum flows. On the other hand, the Q90/Q50 ratio is identical.

Statistically, the validation results were even better than the calibration phase, as shown in the statistical functions obtained (Table 6).

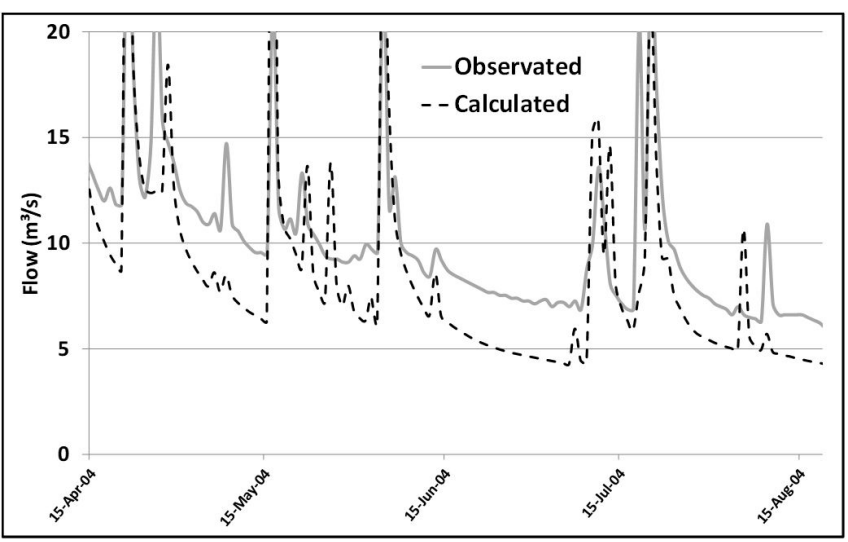

Figure 14. Validation period hydrograph (2004), highlighting the recession curve.

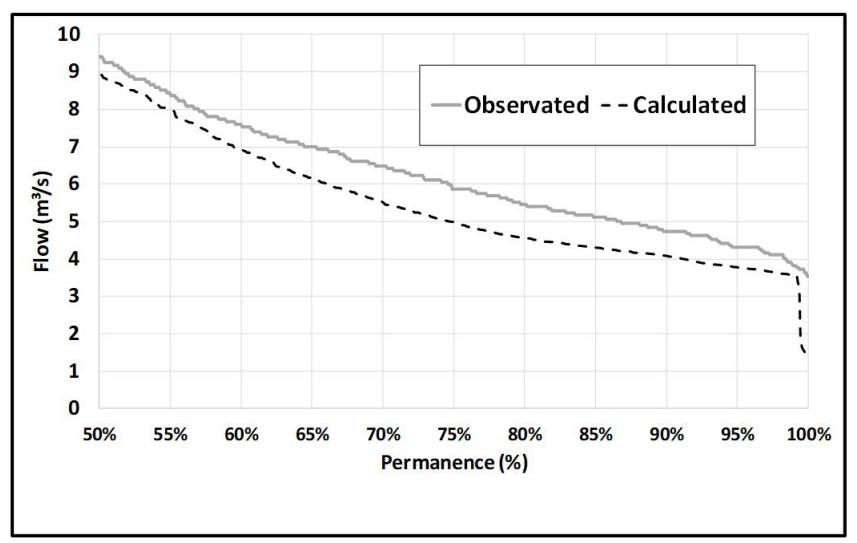

Figure 15. Validation period permanence curves (2002-2004).

Table 5. Validation period reference flows (2002-2004).

\begin{tabular}{ccc}
\hline Reference & $\begin{array}{c}\text { Observed Flow } \\
\left(\mathbf{m}^{\mathbf{3}} \mathbf{s}\right)\end{array}$ & $\begin{array}{c}\text { Simulated Flow } \\
\left(\mathbf{m}^{3} / \mathbf{s}\right)\end{array}$ \\
\hline Q50 & 9.4 & 9.0 \\
Q90 & 4.8 & 4.1 \\
Q95 & 4.4 & 3.8 \\
Q90/Q50 & 0.5 & 0.5 \\
\hline
\end{tabular}

Table 6. Statistical functions obtained during validation.

\begin{tabular}{cc}
\hline Statistical function & Value \\
\hline $\mathrm{R}^{2}$ & 0.76 \\
Nash-Sutcliffe Efficiency (ENS) & 0.71 \\
ENS of the flows natural logarithm & 0.66 \\
Kling-Gupta Efficiency (KGE) & 0.83 \\
\hline
\end{tabular}

Similarly to the calibration period simulation, there was a good representation of the flows seasonal variability, with the hydrograph recessions occurring at the right moments and the baseflow being well represented. The tendency of peak flows overestimations was also repeated. 


\section{Comparisons with previous works}

The model performance was also compared with other models previously performed in the same basin. The first comparison was with MODCEL itself, in its previous version, used in Lou (2010), which incorporated the baseflow through a boundary condition, such that the baseflow was considered constant throughout the whole simulation time, with no real link to the phenomenon physical representation. Figure 16 presents a comparison of the hydrographs obtained in simulation for the year 2002, with the two models already calibrated and validated. Figure 17 highlights the hydrograph recession period, between 04/15/2002 and 08/15/2002.

The difference between the old version of MODCEL, without insertion of baseflow, and the version proposed in this work (new MODCEL) is notorious and emblematic, illustrating the main improvement incorporated into the model - the baseflow physical representation capacity and, therefore, the possibility of simulating flow series in rural and peri-urban basins.

The model used by Lou (2010) is able to represent satisfactorily the flows seasonality. However, it errs considerably in the baseflow, in that it adds a constant value to the hydrograph ordinates, via boundary condition. Even if a boundary condition with time-varying values was adjusted, which would more accurately represent the interannual variation of the baseflow, the physical process governing the baseflow would not be considered - as can be seen in the new MODCEL. Table 7 shows the statistical functions obtained by the two models for the year 2002. In analytical terms, the $\mathrm{R}^{2}$ of 0.74 obtained with the new MODCEL for 2002 , in counterpoint to the $\mathrm{R}^{2}$ of 0.56 obtained in the modeling of Lou (2010), as well as the other calculated indices, illustrate this improvement of representation.

Considering only the recession period, new MODCEL presented $R^{2}$ of 0.75 , against 0.52 obtained in previous model. Figure 18 shows how the permanence curves of the two models behave, focusing on minimum flows, with permanence of $50 \%$ to $100 \%$.

The permanence curves of the observed and calculated flows with the new MODCEL are similar. Simulated flows were slightly underestimated, as had already been observed in the model calibration and validation. On the other hand, the MODCEL previous version misses considerably in the representation of Q50 onwards, with almost constant flow, only presenting values close to those observed from Q80. Table 8 shows these trends in analytical terms, with emphasis on the Q50 underestimation by MODCEL previous version.

Comparisons were also made with the models performed by Gonçalves (2008). A summary of the statistical indices obtained is presented in Table 9 .

The calculated statistical functions show that MODCEL and TOPMODEL models presented a good fit between simulated flows and observed flows, with higher indexes than those obtained in SMAP modeling, especially in terms of Kling-Gupta Efficiency (KGE).

Figure 19 and Table 10 present the comparison of permanence curves and reference flows between new MODCEL and the three models.

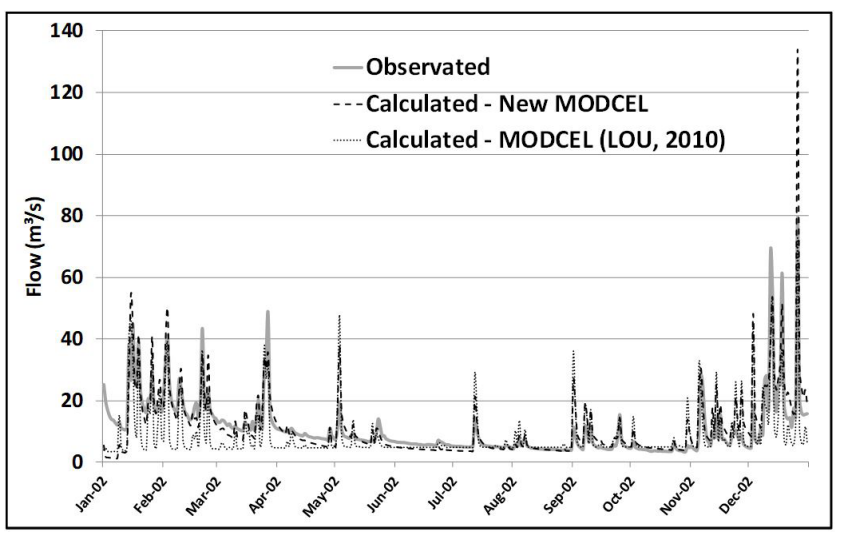

Figure 16. Comparative hydrograph - New MODCEL $\times$ MODCEL (LOU, 2010) - 2002.

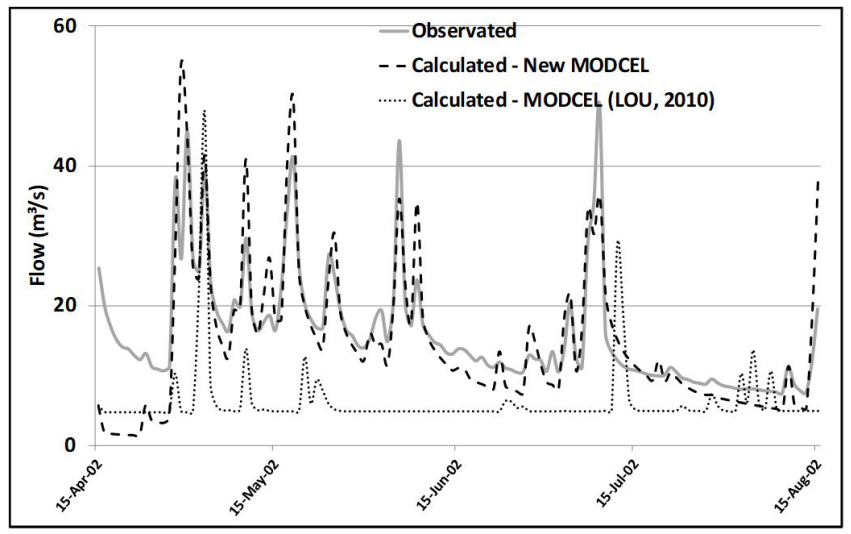

Figure 17. Comparative hydrograph - New MODCEL $\times$ MODCEL (LOU, 2010) - zoom in the hydrograph recession period of 2002.

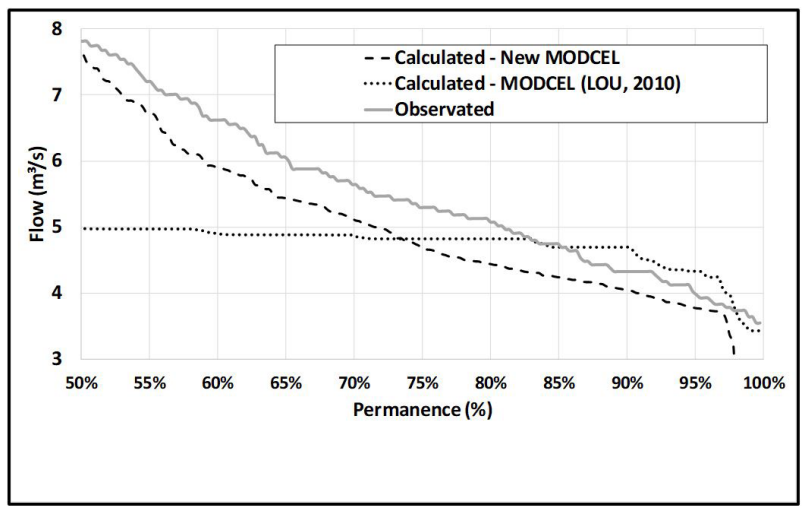

Figure 18. Permanence curves - comparison between new MODCEL and previous version (2002).

Table 7. Statistical functions obtained in comparative modeling -2002 .

\begin{tabular}{ccccc}
\hline Model & $\mathbf{R}^{2}$ & ENS & ENS log & KGE \\
\hline New MODCEL & 0.74 & 0.61 & 0.46 & 0.74 \\
Previous version MODCEL & 0.56 & 0.47 & 0.08 & 0.67 \\
\hline
\end{tabular}


Table 8. Reference flows - comparison between new MODCEL and previous version (2002).

\begin{tabular}{cccc}
\hline Reference & Observed Flow $\left(\mathrm{m}^{3} / \mathbf{s}\right)$ & $\begin{array}{c}\text { Simulated Flow }- \text { New } \\
\text { MODCEL }\left(\mathbf{m}^{3} / \mathbf{s}\right)\end{array}$ & $\begin{array}{c}\text { Simulated Flow - Previous } \\
\text { version } \mathbf{M O D C E L ~}\left(\mathbf{m}^{3} / \mathbf{s}\right)\end{array}$ \\
\hline Q50 & 7.8 & 7.7 & 5.0 \\
Q90 & 4.3 & 4.1 & 4.7 \\
Q95 & 4.1 & 3.8 & 4.3 \\
Q90/Q50 & 0.6 & 0.5 & 0.9 \\
\hline
\end{tabular}

Table 9. Statistical functions obtained in comparative modeling - 2002-2004 period.

\begin{tabular}{ccccc}
\hline Model & $\mathbf{R}^{2}$ & ENS & ENS log & KGE \\
\hline New MODCEL & 0.76 & 0.71 & 0.66 & 0.83 \\
SMAP (Smoothing) & 0.71 & 0.69 & 0.72 & 0.71 \\
SMAP (Rosenbrock) & 0.46 & 0.46 & 0.53 & 0.51 \\
TOPMODEL & 0.75 & 0.73 & 0.82 & 0.86 \\
\hline
\end{tabular}

Table 10. Reference flows - comparison between new MODCEL, SMAP and TOPMODEL (2002-2004).

\begin{tabular}{cccccc}
\hline Reference & $\begin{array}{c}\text { Observed Flow } \\
\left(\mathbf{m}^{3} / \mathbf{s}\right)\end{array}$ & $\begin{array}{c}\text { Simulated Flow } \\
\text { New MODCEL } \\
\left(\mathbf{m}^{3} / \mathbf{s}\right)\end{array}$ & $\begin{array}{c}\text { Simulated Flow - } \\
\text { SMAP/Smoothing } \\
\left(\mathbf{m}^{3} / \mathbf{s}\right)\end{array}$ & $\begin{array}{c}\text { Simulated Flow - } \\
\text { SMAP/Rosenbrock } \\
\left(\mathbf{m}^{3} / \mathbf{s}\right)\end{array}$ & $\begin{array}{c}\text { Simulated Flow } \\
- \text { TOPMODEL } \\
\left(\mathbf{m}^{3} / \mathbf{s}\right)\end{array}$ \\
\hline Q50 & 9.4 & 9.0 & 12.1 & 11.7 & 8.5 \\
Q90 & 4.8 & 4.1 & 6.3 & 6.4 & 4.3 \\
Q95 & 4.4 & 3.8 & 6.0 & 5.9 & 4.1 \\
Q90/Q50 & 0.5 & 0.5 & 0.5 & 0.5 & 0.5 \\
\hline
\end{tabular}

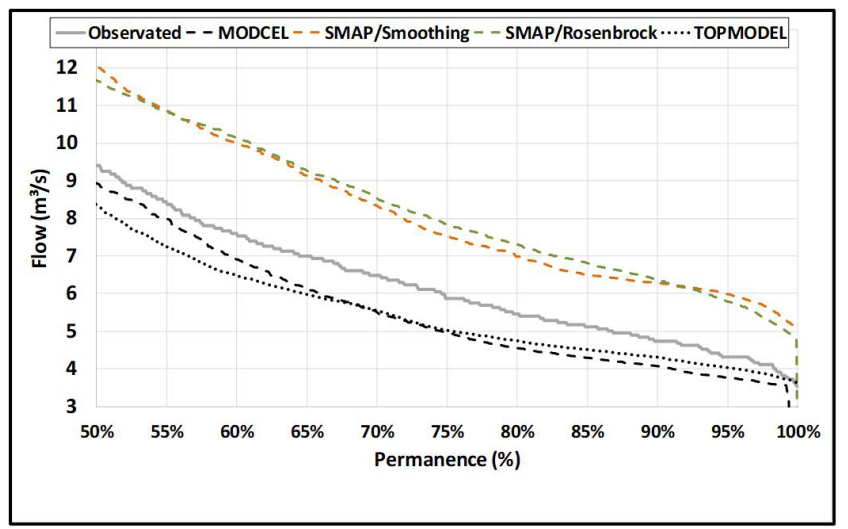

Figure 19. Permanence curves - comparison between new MODCEL, SMAP and TOPMODEL (2002-2004).

As already seen in the calibration/validation phase and in the comparative analysis between the two MODCEL conceptions, the new model is well adjusted to the observed flows in terms of minimum flows, with values slightly lower than those observed.

TOPMODEL's permanence curve presents behavior very similar to MODCEL, with simulated flows slightly lower than the observed flows. The SMAP models, on the other hand, present considerably higher curves, indicating an overestimation trend of the minimum flows.

\section{CONCLUSIONS}

The present work aimed to improve the MODCEL by inserting of a new type of cell and a new type of connection that made possible the baseflow simulation, establishing a link with the physical representation of this phenomenon.
A case study was proposed in a sub-basin of the Piabanha river until Pedro do Rio station. The results were satisfactory. Besides the improvement in the flows seasonality, a good adjustment of the baseflow and of the hydrograph itself as a whole were observed. The statistical functions obtained, as well as the permanence curves and reference flows compared to the observed values, show the model's good behavior. It is necessary to observe, however, the overestimation of some peak flows, possibly due to the spatial scale adopted for the model cells.

Comparisons with previous works that carried out hydrological modeling in the same sub-basin reinforce the good performance of the model, especially against the previous version of MODCEL itself and SMAP. In the hydrograph recession period, the new MODCEL presented $\mathrm{R}^{2}=0.75$, against 0.52 obtained with its previous version. The analysis of the permanence curve and reference flow, with emphasis on the minimum, also show the good behavior of the model in terms of correct representation of the hydrograph recession. Thus, the new model developed is suitable for simulations of complete hydrological years in rural and periurban watersheds, where the baseflow is not negligible.

\section{REFERENCES}

BARBEDO, J.; MIGUEZ, M. G.; VAN DER HORST, D.; MARINS, M. Enhancing ecosystem services for flood mitigation: a conservation strategy for periurban landscapes? Ecology and Society, v. 19, n. 2, p. 54, 2014. http://dx.doi.org/10.5751/ES-06482-190254.

BRITO, P. L. C. Desenvolvimento do módulo para representação de escoamento de base no modelo MODCEL. 2014. 134 f. Dissertação (Mestrado em Engenharia Civil) - Instituto Alberto Luiz Coimbra de Pós-Graduação e Pesquisa em Engenharia, Universidade Federal do Rio de Janeiro, Rio de Janeiro, 2014. 
DE GRAAF, I. E. M.; SUTANUDJAJA, E. H.; VAN BEEK, L. P. H.; BIERKENS, M. F. P. A high-resolution global-scale groundwater model. Hydrology and Earth System Ciences, v. 19, n. 2, p. 823-837, 2015. http://dx.doi.org/10.5194/hess-19-823-2015.

DE GRAAF, I. E. M.; VAN BEEK, R. L. P. H.; GLEESON, T.; MOOSDORF, N.; SCHMITZ, O.; SUTANUDJAJA, E. H.; BIERKENS, M. F. P. A global-scale two-layer transient groundwater model Development and application to groundwater depletion. Advances in Water Resources, v. 102, p. 53-67, 2017. http://dx.doi.org/10.1016/j. advwatres.2017.01.011.

FISRWG - FEDERAL INTERAGENCY STREAM RESTORATION WORKING GROUP. Stream corridor restoration: principles, processes and practices. Washington: NRCS, 2001. Available from: <http:// www.nrcs.usda.gov/technical/stream_restoration>. Access on: 09 mar. 2017.

GONÇALVES, R. C. Modelagem bidrológica do tipo chuva-vazãa via SMAP e TOPMODEL - estudo de caso: Bacia do Rio Piabanha/RJ. 2008. 173 f. Dissertação (Mestrado em Engenharia Civil) - Instituto Alberto Luiz Coimbra de Pós-Graduação e Pesquisa em Engenharia, Universidade Federal do Rio de Janeiro, Rio de Janeiro, 2008.

LOU, R. F. Modelagem hidrológica chuva-vazão e hidrodinâmica aplicada na bacia experimental do Rio Piabanba/RJ. 2010. 174 f. Dissertação (Mestrado em Engenharia Civil) - Instituto Alberto Luiz Coimbra de Pós-Graduação e Pesquisa em Engenharia, Universidade Federal do Rio de Janeiro, Rio de Janeiro, 2010.

MASCARENHAS, F. C. B.; MIGUEZ, M. G. Urban flood control through a mathematical cell model. Water International, v. 27, n. 2, p. 208-218, 2002. https://doi.org/10.1080/02508060208686994.

MIGUEZ, M. G. Modelo matemático de células de escoamento para bacias urbanas. 2001. 410 f. Tese (Doutorado em Engenharia Civil) - Instituto Alberto Luiz Coimbra de Pós-Graduação e Pesquisa em Engenharia, Universidade Federal do Rio de Janeiro, Rio de Janeiro, 2001.

MIGUEZ, M. G.; MASCARENHAS, F. C. B.; MAGALHÃES, L. P. C.; D'ALTERIO, C. F. V. Planning and Design of Urban Flood Control Measures: Assessing Effects Combination. J. Urban Plan, v. 135, n. 3, p. 100-109, 2009. http://dx.doi.org/10.1061/(ASCE) UP.1943-5444.0000012.

MIGUEZ, M. G.; MASCARENHAS, F. C.; VERÓL, A. P.MODCEL: a mathematical model for urban flood simulation and integrated flood control design. In: Acqua e Cittá 2011 - $4^{\circ}$ Convegno Naz̧ionale de Idraulica Urbana, 4., 21-24 giugno 2011, Venezia. Rio de Janeiro: AquaFluxus, 2011. p. 1-17. Available from: < http:/ / aquafluxus.com. br/wp-content/uploads/2012/03/MODCEL_A_Mathematical_ Model_For_Urban_Flood_Simulation_and_Flood_Control_Design. pdf $>$. Access on: 09 mar. 2017.

MIGUEZ, M. G.; VERÓL, A. P.; MASCARENHAS, F. C. B.; SANTOS, R. B. Storage measures as compensatory techniques for urban lowlands flood control. International Journal of Sustainable Development and Planning, v. 9, n. 2, p. 225-236, 2014. http://dx.doi. org/10.2495/SDP-V9-N2-225-236.

MIGUEZ, M. G.; VERÓL, A. P.; REZENDE, O. M. Drenagem urbana: do projeto tradicional à sustentabilidade. Rio de Janeiro: Elsevier, 2015a. 384 p.
MIGUEZ, M.; VERÓL, A.; SOUSA, M.; REZENDE, O. Urban floods in lowlands - levee systems, unplanned urban growth and river restoration alternative: a case study in Brazil. Sustainability, v. 7, n. 8, p. 11068-11097, 2015b. http://dx.doi.org/10.3390/su70811068.

REZENDE, O. M; MIGUEZ, M. G.; VERÓL, A. P. Manejo de águas urbanas e sua relação com o desenvolvimento urbano em bases sustentáveis integradas — estudo de caso dos Rios Pilar-Calombé, em Duque de Caxias/RJ. Revista Brasileira de Recursos Hídricos, v. 18, n. 2, p. 149-163, 2013. http://dx.doi.org/10.21168/rbrh.v18n2.p149-163.

ROSENBROCK, H. An automatic method for finding the greatest or least value of a function. The Computer Journal, v. 3, n. 3, p. 175-184, 1960. http://dx.doi.org/10.1093/comjnl/3.3.175.

TUCCI, C. E.; SILVEIRA, A. L.; BENETTI, A.; LANNA, A. E. Hidrologia-ciência e aplicação. 4. ed. Porto Alegre: Editora da UFRGS, 2009.

VERÓL, A. P. (2010). Simulação da propagação de onda decorrente de ruptura de barragem, considerando a planície de inundacão associada a partir da utilização de um modelo psendo-bidimensional. 2010. 217 f. Dissertação (Mestrado em Engenharia Civil) - Instituto Alberto Luiz Coimbra de Pós-Graduação e Pesquisa em Engenharia, Universidade Federal do Rio de Janeiro, Rio de Janeiro, 2010.

VERÓL, A. P.; MIGUEZ, M. G.; MASCARENHAS, F. C. B. Propagação da onda de ruptura de barragem através de um modelo Quasi-2D. Revista Brasileira de Recursos Hídricos, v. 18, n. 1, p. 165-176, 2013. http://dx.doi.org/10.21168/rbrh.v18n1.p165-176.

WADA, Y.; WISSER, W.; BIERKENS, M. F. P. Global modeling of withdrawal, allocation and consumptive use of surface water and groundwater resources. Earth System Dynamics, v. 5, n. 1, p. 15-40, 2014. http://dx.doi.org/10.5194/esd-5-15-2014.

XAVIER, A. E.; ROT'TUNO FILHO, O. C.; CANEDO, P. M.; SILVA, L. P. A new deterministic approach in calibration of Rainfall-Runoff models: the hyperbolic smoothing method. In: EURO Conference 2001, 2001, Rotterdam, The Netherlands. Association of European Operational Research Societies, 2001.

ZANOBETTI, D.; LORGERÉ, H.; PREISSMAN, A.; CUNGE, J. A. Mekong delta mathematical program construction. Journal of The Waterways and Harbours Division, v. 96, n. 2, p. 181-199, 1970.

\section{Authors contributions}

Pedro Lucas Cosmo de Brito: Literature research, data collect, data processing, modeling design, model simulation, interpretation and discussion of results, writing and formatting of the paper.

Marcelo Gomes Miguez: Advisor, model's computational implementation, modeling design, interpretation and discussion of results, review, text correction.

José Paulo Soares de Azevedo: Advisor, work conception, interpretation and discussion of results, review. 


\section{APPENDIX A. MODCEL DESCRIPTION}

MODCEL's basic premise is the possibility of dividing the region of interest into homogeneous cells (or compartments), which are connected through links capable of representing the exchange of flows between them. The flow cells can represent either hydraulic structures or landscapes (natural or urban), in an arrangement such that it allows diverse flow patterns, inside or outside the drainage network, from interactions between the modeled cells.

MODCEL's spatial representation links surface flow, channel flow and underground pipe flow. This arrangement can be interpreted as a quasi-2D model, with links given by one-dimensional equations. However, since the model can represent surface flow (surface channels and flooded areas) and underground flow (drainage galleries), which are connected vertically through hydraulic links, it can be considered a quasi-3D model, because it represents schematically a three-dimensional reality (REZENDE et al., 2013; MIGUEZ et al., 2015b).

MODCEL's basic premises are as follows:

- The system (landscape and drainage network) can be represented by homogeneous, interconnected compartments, referred to as flow cells, forming a two-dimensional flow network, with possibility of flow in several directions in the flood zones, from one-dimensional exchange relations;

- Each cell receives rainfall contribution and performs internal hydrological processes to transform rainfall into flow;

- In the cell, the free surface profile is considered horizontal, the area of this surface depends on the elevation of the water level inside the cell and the volume of water contained in each cell is directly related to the water level in its center;

- Each cell communicates with neighboring cells, which are arranged in a topological scheme, consisting of formal groups, where a cell of a given group can only communicate with cells of this same group, or groups immediately after or before;

- The flow between cells can be calculated by known hydraulic laws, such as the Saint-Venant dynamic equation, complete or simplified, the flow equation on spillways (free or drowned), the flow equation through holes, flow equations micro drainage abstractions by drain boxes, among others;

- The flow between two adjacent cells at any time is only a function of the water levels in the center of these cells;

- Cross-sections of flow are taken as equivalent rectangular sections, simple or composite;

- The flow can occur simultaneously in two layers, one superficial and the other subterranean, in gallery, and there may be communication between the surface and gallery cells. In the galleries, the flow is considered initially to the free surface, but may suffer a surcharge, being considered under pressure.

- In MODCEL, space representation can be done by assigning the following types to cells:

- River or channel cells: are cells on which the flow in rivers and channels develop, constituting the main drainage flow in the open air;

- Underground gallery cells: represent sections of closed channels of an urban basin, constituting the underground drainage network;

- Urbanised superficial cells: are cells that represent urbanized areas, with a given pattern urbanization pattern pre-defined by the modeler, which defines the average depth of streets and building sills, as well as the percentage of streets, sidewalks, squares and buildings, and can define a storage area different from total area;

- Natural superficial cells: are cells that represent natural areas, without urbanization, being defined a storage area, which excludes the elevations present in that area for purposes of mass balance;

- Reservoir cells: simulate the water storage in a temporary reservoir, and can also represent, through its curve depth-area, the topography of an irregular natural surface.

- MODCEL performs flow changes between cells by means of the following types of links:

- River/Channel Link;

- Broad crested weir Link;

- Orifice Link;

- Surface Flow Link;

- Inlet gallery Link;

- Outlet gallery Link;

- Gallery Link;

- Gallery Discharge into an Open Channel Link;

- Inlet Link;

- Pumping Link;

- Flap gate Link;

- Reservoir Link;

- Stage-Discharge Curve Link. 